
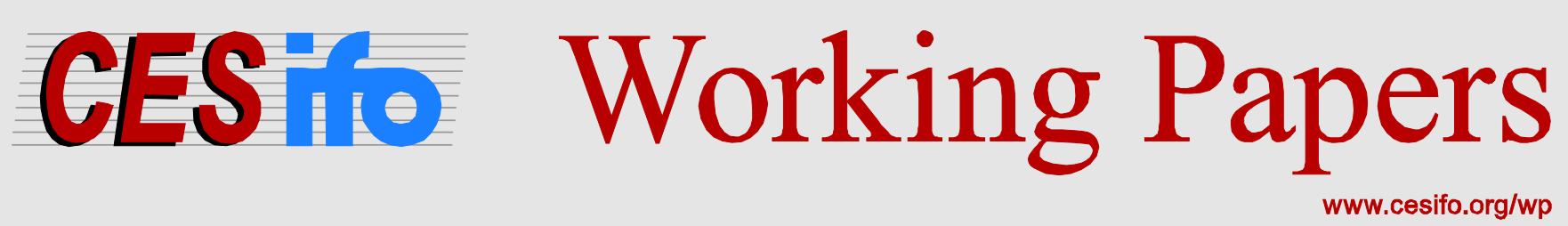

\title{
Heterogeneous Beliefs and the Demand for D\&O Insurance by Listed Companies
}

\author{
Peter Egger \\ Doina Radulescu \\ Ray Rees
}

CESIFO WORKING PAPER NO. 4621

CATEGORY 11: INDUSTRIAL ORGANISATION

JANUARY 2014

An electronic version of the paper may be downloaded

- from the SSRN website:

- from the RePEc website:

- from the CESifo website:

WWW.SSRN.com

www.RePEc.org

www.CESifo-group.org/wp

\section{CESifo}




\title{
Heterogeneous Beliefs and the Demand for D\&O Insurance by Listed Companies
}

\begin{abstract}
This paper introduces a new rationale for the existence of "Directors' and Officers'” (D\&O) insurance. We use a model with volatile stock markets where shareholders design compensation schemes that incentivize managers to stimulate short-term increases in stock prices that do not maximize long run stock market value. We show that D\&O insurance provides a convenient instrument for the initial shareholders of a company to take advantage of differences in beliefs between insiders and outsiders in capital markets. The empirical results support the idea that both the insurance coverage and the premium are higher in the presence of new shareholders and volatile markets. The results prove robust in various empirical model specifications.
\end{abstract}

JEL-Code: G220, G300, C230, M520.

Keywords: D\&O insurance, volatile markets, credible protection, panel data models.

\author{
Peter Egger \\ ETH Zurich \\ Weinbergstr. 35 \\ Switzerland - 8092 Zurich \\ egger@kof.ethz.ch
}

Doina Radulescu

ETH Zurich

Weinbergstr. 35

Switzerland - 8092 Zurich

radulescu@kof.ethz.ch

Ray Rees

Professor Emeritus, University of Munich

\& Associate Fellow, University of Warwick

ray.rees@Irz.uni-muenchen.de

January 8, 2014 


\section{Introduction}

The existence of the "Directors' and Officers'" (D\&O) insurance market presents something of a paradox and raises issues that seem to call for public policy intervention. It could be argued that the ability of shareholders to hold board members and senior executives personally liable for mismanagement of the company, by being able to take them to court and extract damages if such mismanagement - the breach of fiduciary duty towards shareholders - is established, is an important instrument of corporate governance. To allow these same board members and executives to be indemnified against the costs of such proceedings, as D\&O insurance appears to allow, apparently removes this instrument, and, to add insult to injury, the cost of the insurance is borne by shareholders. The moral hazard problem appears obvious. This has led to calls to outlaw or regulate the D\&O insurance market, ${ }^{1}$ which can be expected to grow as the market itself grows and the sequence of financial crises and corporate scandals continues.

If managerial remuneration is part of the agency problem rather than a solution to it, as argued for instance by Bebchuk and Fried (2004), the existence of D\&O insurance seems to support the hypothesis that directors and senior managers run companies in their own interests rather than those of shareholders. However, recent contributions to the literature on the economics of agency suggest that this view could be questioned. Bolton, Scheinkman, and Xiong (2006) propose an alternative explanation of managerial remuneration contracts based on a challenge to a basic assumption about the stock market that is taken as given in the literature. This is that the stock market value of the firm always appropriately reflects its underlying long run fundamental value. Against this, Bolton, Scheinkman, and Xiong argue that the experience of stock market bubbles in the past decade suggests that large movements in stock prices are driven by short run profit motives that cause stock prices to deviate significantly from their fundamental values. It can be therefore in the interests of an initial group of shareholders to provide incentives to managers to take decisions - "undertake projects" - that stimulate such short term bubbles, allowing them to make capital gains by selling their shares to new investors with higher profit expectations. Thus, as with the traditional approach, the initial shareholders design incentive schemes which align the interests of

\footnotetext{
${ }^{1}$ See for example the article in the Economist, (12 June 2003) with the headline: "Double Indemnity: Company Executives Should Pay For Their Own Mistakes".
} 
directors and top executives with theirs, but in a way that does not maximize the long-run value of the company.

This suggests a reinterpretation of the reason for the existence of D\&O insurance, as a credible promise to senior management to cover the risk that they may be sued by future shareholders in the event that the profit expectations they held when they bought the company's shares are disappointed. An alternative would be to make up-front payments, but the model presented in this paper shows that when directors and officers are risk averse it is less costly for the initial shareholders to provide them with $\mathrm{D} \& \mathrm{O}$ insurance. We do not argue of course that this is the only motive for large companies to buy D\&O insurance, or that all such companies conform to this model. We believe however that it is an interesting and quite realistic hypothesis about a possible aspect of $\mathrm{D} \& \mathrm{O}$ insurance demand that deserves to be taken to the data.

An important related contribution, which in some respects anticipates the idea underlying the Bolton, Scheinkman, and Xiong model, is that by Chalmers, Dann, and Harford (2002). They examine the three-year post-IPO performance of firms' shares and show that this is negatively correlated with the D\&O insurance coverage taken out by those firms just prior to the IPO. They interpret this as evidence that managers who are behaving opportunistically, by timing the IPO to coincide with what they know is an overvaluation of the company's shares, seek to protect themselves against being sued because of the following poor performance of the shares. They suggest that "[o]ne cost of selling overvalued equity is that directors and officers face an increased likelihood of being sued by disgruntled shareholders". ${ }^{2}$

This is also a central idea of this paper. Chalmers, Dann, and Harford see it as supporting something like a Bebchuk-Fried theory of corporate governance. They do not however adduce evidence to show that the managers were not in fact acting with the full agreement of the then owners of the firm, who also stood to gain, in timing the IPO to coincide with its current overvaluation. This therefore remains an open question, and one on which this paper attempts to shed light.

Overall, the number of studies dealing with D\&O insurance is relatively small. Parry and Parry (1991) use a standard agency model with D\&O insurance as a component of managerial remuneration and carry out a comparative static analysis of the optimal compensation package with respect to the loss distribution and insurance premium. Gutierrez (2003) employs a principal-agent

\footnotetext{
${ }^{2}$ Chalmers, Dann and Harford (2002) p.610.
} 
model and a three-stage dynamic game of complete but imperfect information. The shareholders can take legal action against the director and the court's decision provides a verifiable, costly and imperfect signal about the agent's fulfillment of fiduciary duties, thus allowing her remuneration to be made contingent on the court's decision. Gutierez shows that given damage awards are high enough, liability insurance is optimal because it allows for a more efficient litigation strategy to be ex-post rational for the shareholders.

In addition to Chalmers, Dann and Harford already discussed, O'Sullivan (1997), Core (1997), Bhagat, Brickley, and Cole (1987) and Boyer (2003b), present empirical analyses. O'Sullivan examines the link between the purchase of D\&O insurance and managerial ownership, board composition and the presence of large outside shareholders for a sample of publicly owned UK companies. The results suggest that as firm size increases so do the costs of external ownership as a monitoring device, so that larger firms are more likely to use D\&O insurance as a means of monitoring. Moreover, the study confirms the hypothesis that executive ownership and D\&O insurance can be interpreted as substitute monitoring devices. Core (1997) examines the determinants of D\&O insurance demand for a sample of Canadian firms. His findings suggest that firms with greater litigation risk and distress probability, as well as firms in the utilities sector, are more likely to purchase insurance, whereas firms with greater inside ownership are less likely to purchase insurance. However, in contrast to O'Sullivan, Core does not find evidence that director cash compensation substitutes for $\mathrm{D} \& \mathrm{O}$.

Among the more recent articles on D\&O insurance are the contributions by Cao and Narayanamoorthy (2011), Lin, Officer, and Zou (2011), Boyer and Stern (2012) and Gupta and Prakash (2012). Cao and Narayanamoorthy's (2011) results support the litigation risk hypothesis. They examine the consequences of litigation risk (reflected by $\mathrm{D} \& \mathrm{O}$ premia) on the decision of management to issue earnings forecasts. In the presence of ex-ante litigation risk, managers with bad news are more likely to provide bad-news earnings forecasts. This is not the case for companies with good earnings news. Lin, Officer, and Zou (2011) explore the impact of D\&O insurance on the outcomes of M\&A deals. Their findings indicate that the acquisition premia are higher the larger the D\&O protection of acquirers is. The latter supports the hypothesis that D\&O insurance can be a cause of moral hazard by limiting the disciplining effects of shareholder litigation. Further evidence for the corporate governance risk hypothesis is provided by Boyer and Stern (2012), who find that 
income trusts, which are characterised by a riskier ownership form, pay higher D\&O premia than common equity firms. As opposed to previous studies, Gupta and Prakash (2012) find that, besides governance quality, D\&O insurance also reflects managers' private information. Their results suggest that $\mathrm{D} \& \mathrm{O}$ coverage limits are lower the larger the insider control is that goes beyond insider shareholdings.

Given that some opponents of this type of insurance argue that D\&O insurance harms shareholders through adverse incentive effects, Bhagat, Brickley, and Cole (1987) consider the effects of D\&O insurance on shareholder wealth for a sample of New York-traded publicly chartered firms. They find, on average, a positive relationship between the two variables, and thus conclude that under certain circumstances D\&O insurance might even align the interests of shareholders and managers. The idea that D\&O insurance can be interpreted as a means to protect the shareholders rather than managers also finds support in Boyer's (2003b) paper. Using a sample of 354 Canadian corporations for the years 1992-1998, Boyer's results suggest that the demand for D\&O insurance, as a directors' compensation component, is a means of shareholders' wealth protection. Moreover, the existence of such insurance can substitute for monitoring by financial institutions.

In this paper we interpret the theoretical model by Bolton, Scheinkman, and Xiong (2006), though it does not itself deal with D\&O insurance, as suggesting an entirely new rationale for this controversial form of indemnifying managers against the consequences of their decisions. We begin by developing this idea in a model that is much simpler than theirs, but also more amenable to empirical testing, extend it to incorporate $\mathrm{D} \& \mathrm{O}$ insurance, and then go on to carry out the empirical tests. The next section gives a brief overview of the D\&O insurance market. In Sections 3 and 4 we present the model and analyse the insurance decision, and the empirical analysis follows in Section 5. Section 6 presents our concluding remarks.

\section{D\&O Insurance}

A D\&O insurance policy is purchased and owned by the firm but indemnifies its directors and officers against the costs of being sued. In case of a lawsuit against an individual director or senior executive, ${ }^{3}$ the D\&O policy reimburses the associated costs, provided the director or executive is

\footnotetext{
${ }^{3}$ Roughly $50 \%$ of cases are brought by shareholders, the remainder by employees, customers, suppliers etc.
} 
shown to have acted honestly and in good faith, in the best interests of the company as perceived at the time. Two types of insurance are common: corporate coverage which reimburses the firm when it indemnifies a director or senior executive for the costs of a suit; and personal coverage which provides direct payment to a director or senior executive when the firm is not able to indemnify him or her.

D\&O insurance was first introduced in Germany in 1895, but it was soon banned by the Imperial Insurance Office on grounds of being considered immoral. In the US in 1929, following the stock market crash, new laws were enacted to improve investor protection and prevent directors from abusing corporate indemnification provisions at shareholders' expense. At that time, since companies did not indemnify directors against compensation claims, Lloyd's of London developed a D\&O insurance product.

In the 1960s, changes in the interpretation of the securities laws created the realistic possibility that directors and officers themselves, and not only corporations, could face significant liability. However it was not until the 1980s that the D\&O market really started to develop. Nowadays, the demand for such insurance is high, given the frequent suits against directors and senior executives by customers, shareholders and other third parties, but the market and the contract characteristics differ to a large extent between the USA and Europe, and significant differences exist even among European countries. In the US, D\&O insurance is common and $95 \%$ of Fortune 500 companies hold D\&O policies, whereas in Germany around $70 \%$ of all enterprises have such a policy.

According toTowers Watson (2009), a company that surveys 2,599 U.S participants, the average amount of coverage across the survey's participants amounted to US\$10.61 mn in 2008. The largest companies with assets exceeding US $\$ 10$ bn purchased policies with coverage amounting to an average of US $\$ 128.75 \mathrm{mn}$. The mean deductible across all companies amounted to US\$191,000, or roughly $2 \%$ of the average coverage bought. Participants with assets exceeding US $\$ 10$ bn carried average deductibles of US\$3,621 mn, or around $3 \%$ of average cover. Not only are these deductibles on average small, but one frequently encounters in the data companies where no deductibles are set at all, especially in the second type of policy - personal indemnity for a director or executive. Since deductibles are a standard means of dealing with moral hazard, this suggests that this is, perhaps surprisingly, not perceived as a serious problem by insurers in this area. ${ }^{4}$

\footnotetext{
${ }^{4}$ At this kind fof level one might conclude that the deductibles exist to avoid the transactions costs associated
} 
In discussions with insurers we were given as possible explanations for this first, the fact that legal infringements such as fraud and deception automatically nullify the insurance contract, and secondly, that these contracts are not "over the counter" standard products - a considerable amount of monitoring, including inspection of the records of directors and executives, and discussion of the company's corporate governance regime, takes place before the contract is concluded. ${ }^{5}$ Where insurers have serious doubts, we were told, they prefer not to offer the contract. Thus it would seem that asymmetric information between insurer and insured does not play a significant role in this market.

The large amounts of money involved in lawsuit settlements in the US and in Europe respectively suggest the quantitative significance of this market. In the past years, the largest settlements in the US involved Enron with US\$7.2 bn in 2006, WorldCom with US $\$ 6.2$ bn in 2005 , Cendant Corp. with US\$3.5 bn in 1999 and Tyco International with US\$3.2 bn in 2007 (Ryan and Simmons, 2008). In Europe, though the amounts are smaller, the issue is still important. The largest settlements involved Deutsche Telekom AG with US\$120 mn in Germany in 2004, Otto GmbH with US\$104mn in 2005 and Royal Dutch Petroleum with US\$90 mn in the Netherlands in 2005 (GenRe, 2005).

\section{The Model}

The paper by Bolton, Scheinkman, and Xiong presents a very general model which, for our purposes here, suffers from the drawback that it does not have a closed analytical form for its solution. An explicit solution is given for the case in which the agent - the CEO of a large joint stock company - is risk neutral, but this is not very appealing, since it is based on the familiar result that in this case the optimum is for the owners to sell the company to the agent. Otherwise, in the case of a risk averse agent there are only numerical examples of possible equilibria.

Here, we set up a much simpler model which, we would argue, captures the central insights of the Bolton, Scheinkman, and Xiong model while allowing an analytical solution. This forms the basis for an extension of the model to the case in which the agent receives $\mathrm{D} \& \mathrm{O}$ insurance as part of her compensation package, and allows us to carry out the comparative static analysis that tells with small claims.

${ }^{5}$ Indeed it has been suggested by Mayers and Smith (1982) that this is one of the explanations of why risk-neutral companies would buy insurance in the first place. 
us what we should expect when we take the model to the data.

There are three time periods, $t=0,1,2$. At $t=0$, the initial shareholders, $I$, offer manager ${ }^{6} M$ a contract, which must meet participation and incentive compatibility constraints. $M$ chooses effort levels $e_{s} \in\{0,1\}$ and $e_{l} \in\{0,1\}$ to put into a "short term" project ${ }^{7}$ and a "long term" project, respectively. The respective projects return $s \in\left\{s_{1}, s_{2}\right\}, l \in\left\{l_{1}, l_{2}\right\}$, with $s_{1}<s_{2}, l_{1}<l_{2}$. The (independent) probabilities of $l_{2}$ and $s_{2}$, known only to the $I$-shareholders and $M$, are functions $\pi_{l}\left(e_{l}\right)$ and $\pi_{s}\left(e_{s}\right)$, with $0 \leq \pi_{i}(0)<\pi_{i}(1)<1, i=s, l$.

At $t=1$ there is a publicly observed signal $\sigma \in\left\{\sigma_{1}, \sigma_{2}\right\}$ with $\sigma_{2}>\sigma_{1}$, which gives information about $s$, allowing stock market participants outside the company to form their probability beliefs about the value of the firm at time 2 . For simplicity we assume that the outcome of the $l$-project is observed at this time. ${ }^{8} I$-investors, whose beliefs are unaffected by this signal, may at this point sell their shares to new investors, $N$. The probability of the signal $\sigma_{2}$ is given by $\pi_{\sigma}\left(e_{s}\right)$ with $0 \leq \pi_{\sigma}(0)<\pi_{\sigma}(1)<1$.

At $t=2$, the outcome of the $s$-project is observed. All investors are risk neutral while $M$, who holds the same probability beliefs as the $I$-shareholders, is risk averse.

The key assumption of the model is that "good news", $\sigma=\sigma_{2}$ makes $N$-investors "more optimistic" about returns $s$ to the "short term" project than the $I$-shareholders. We model this by making:

\section{Assumption 1:}

$$
P_{N}\left(s_{2} \mid \sigma_{2}\right)>P_{I}\left(s_{2} \mid \sigma_{2}\right)=\pi_{s}(1)
$$

$N$-investors have a higher conditional probability belief than $I$-shareholders that the higher outcome will be received if the signal is the more favourable one. For simplicity we also make

\section{Assumption 2:}

The interest rate is zero ${ }^{9}$ and short sales by $I$ and $M$ are ruled out.

At $t=0$ the $I$-shareholders offer $M$ a contract which gives her the incentive to choose what are for them the optimal effort levels $\left(e_{l}, e_{s}\right) \in\{0,1\} \otimes\{0,1\}$. A priori all four effort pairs could be

\footnotetext{
${ }^{6}$ In reality of course there is a group of directors and senior executives who receive insurance protection, but we simplify here to a single agent since we are not interested in the decision process within this group.

${ }^{7}$ Bolton, Scheinkman and Xiong refer to this as a "castle in the air" project.

${ }^{8}$ This can represent the continuation of the traditional core activities of the firm.

${ }^{9}$ This is just for simplicity of notation.
} 
optimal, but to restrict attention to the cases of interest we make

\section{Assumption 3:}

Given the inequality of the probabilities held by $N$ and $I$ in (1), then the optimal contract that

the $I$-shareholders offer $M$ implements $\left(e_{l}, e_{s}\right)=(1,1)$. In the absence of this inequality $I$ would want $e_{s}=0$.

Thus, the presence of, from the $I$-shareholders' point of view, "over-optimistic" or $N$-investors makes it profitable to give $M$ an incentive to put effort into the short term project.

M's utility function: is $u(w)-\psi\left(e_{l}, e_{s}\right)$, with $u(w)$ strictly concave and $\psi\left(e_{l}, e_{s}\right)$ convex, and both functions strictly increasing.

If, given (1), at $t=1$ the signal is $\sigma_{2}$, and ignoring for the moment the possibility of suing $M$, $N$-investors value the firm (gross of $M$ 's payoff) at

$$
v_{i}^{N}=l_{i}+\sum_{k=1}^{2} P_{N}\left(s_{k} \mid \sigma_{2}\right) s_{k} \quad i=1,2
$$

depending on the outcome of the $l$-project, which by assumption is known at $t=1$.

If $\sigma_{1}$ is observed, $I$-investors sell no shares at $t=1$ and receive at $t=2$ the value of the firm (again gross of $M$ 's payoff)

$$
v_{i k}^{I}=l_{i}+s_{k} \quad i, k=1,2
$$

Again for simplicity we make:

Assumption 4: When the signal at $t=1$ is $\sigma_{2}, N$-investors pay their valuations for the firm's shares, which are therefore the payoffs to the $I$-investors in these states.

This concludes the presentation of our simplified version of the Bolton, Scheinkman, and Xiong model. We now introduce the possibility that the $N$-investors may sue $M$ ex post, while the $I$ shareholders can take out a $\mathrm{D} \& \mathrm{O}$ insurance policy at $t=0$ to indemnify $M$ against the consequences of this.

\section{The Insurance Decision}

In the event that the signal at $t=1$ is $\sigma_{2}$, the $N$-investors who have bought into the company may at $t=2$ sue $M$ if they are dissatisfied with the firm's performance. In fact we make 


\section{Assumption 5:}

If $M$ is sued, she loses and has to pay $D .{ }^{10} \quad N$-shareholders sue if and only if $s=s_{1} \cdot{ }^{11} I$ shareholders never sue.

An immediate consequence of this assumption is that $N$-shareholders' valuation at $t=1$, given that they will sue and receive $D$ ex post when $s=s_{1}$, become ex ante

$$
\hat{v}_{i}^{N}=l_{i}+P_{N}\left(s_{1} \mid \sigma_{2}\right)\left(s_{1}+D\right)+P_{N}\left(s_{2} \mid \sigma_{2}\right) s_{2} \quad i=1,2
$$

Assumption 4 then implies that $\hat{v}_{i}^{N}$ becomes the value of the firm to the $I$-shareholders at $t=1$ given the occurrence of the signal $\sigma_{2}$. The share price in that event capitalises the expected return to $N$-shareholders of suing at $t=2$ when $s_{1}$ is the outcome, so this benefit essentially flows to the $I$-shareholders, regardless of whether and how they choose to indemnify $M$.

A competitive insurance market exists at $t=0$, which offers $\mathrm{D} \& \mathrm{O}$ insurance at a premium, $r$. Given Assumption 5, the prior probability (held by $I$-shareholders and $M$ ) at $t=0$ of $M$ being sued at $t=2$, given that $e_{s}=1$ is implemented, is

$$
p=\left(1-\pi_{s}(1)\right) \pi_{\sigma}(1)
$$

$\bar{D}=p D$ is therefore the expected cost at $t=0$ of being sued at $t=2$. Then, if full cover is bought, and given that the insurer also believes that the probability of $M$ being sued ${ }^{12}$ is $p$, we can write the premium as $r=(1+\lambda) \bar{D}$, where $\lambda \geq 0$ is a premium loading.

Why would the risk-neutral $I$-shareholders buy full cover for $M$ even at a positive loading $\lambda>0$ ? If they promised to pay $D$ to $M$ in the event she is sued, this would only cost them $\bar{D}$. The problem is that this is not a credible promise, since by that time the $I$-shareholders have sold their shares and moved on. The important point about buying D\&O insurance at $t=0$ is that it is a credible commitment ${ }^{13}$ to fully compensating $M$ in the event she is sued. The only credible alternative would be an upfront payment to $M$ at $t=0$, which satisfies her participation constraint

\footnotetext{
${ }^{10}$ To make the outcome of the case probabilistic would be more realistic but changes nothing qualitative in the results.

${ }^{11}$ There is clearly no reason for them to sue if their over-optimistic expectations, relative to those of $I$ and $M$, are in fact fulfilled.

${ }^{12}$ Recall the discussion in the Introduction concenring the absence of moral hazard in this market.

${ }^{13}$ Assuming a zero risk of insolvency of the insurer.
} 
given the probability of eventually being sued. We now prove that, because $M$ is risk averse, the $I$-shareholders will always prefer to buy the insurance even at a positive loading as long as it is not "too high":

\section{Proposition:}

On the assumptions of the model, there is a critical loading $\lambda^{*}>0$ such that for $\lambda \leq \lambda^{*}$, the I-shareholders will always prefer to buy DEO insurance rather than compensate $M$ by an up-front payment.

Proof: Let the subscript $(i j k)$ denote the state of the world $\left\{l_{i}, \sigma_{j}, s_{k}\right\}, i, j, k=1,2$, with $\pi_{i j k}$ their associated probabilities as perceived by the $I$-shareholders and $M$. Given that $M$ is to implement $\left(e_{l}, e_{s}\right)=(1,1)$, let $\left[w_{i j k}^{*}\right]$ be a vector of payments that satisfies all participation and incentive compatibility constraints in the absence of the possibility of $M$ being sued. In particular therefore

$$
\sum_{i, j, k} \pi_{i j k} u\left(w_{i j k}^{*}\right)=\psi(1,1) \quad i, j, k=1,2
$$

where the value of her outside option is normalised to zero. When $M$ can be sued but full cover D\&O insurance is bought, the same payment vector can be implemented. The cost of this to $I$-shareholders is the lump sum

$$
C=\pi_{\sigma}(1)\left[\left(1-\pi_{s}(1)\right)(1+\lambda)-P_{N}\left(s_{1} \mid \sigma_{2}\right)\right] D
$$

which is the cost of the premium minus the gain in the value of the shares at $t=1$, which we assumed was captured by the $I$-shareholders. When instead an up front payment, say $d$, is made, for the participation constraint to continue to be satisfied we must have

$$
\pi_{121} u\left(w_{121}^{*}-D+d\right)+\pi_{221} u\left(w_{221}^{*}-D+d\right)+\sum_{i, 1, k} \pi_{i 1 k} u\left(w_{i 1 k}^{*}+d\right)=\sum_{i, j, k} \pi_{i j k} u\left(w_{i j k}^{*}\right)
$$

Clearly we must have $d<D$, and so the vector of payments on the left hand side of this equation is a mean-increasing spread of the original distribution, since two of the payments are smaller, all the remaining payments are larger, and they have to yield the same expected utility. It follows that 


$$
d>\left(\pi_{121}+\pi_{221}\right) D=\bar{D}
$$

Then, D\&O insurance will be bought if and only if $d-\pi_{\sigma}(1) P_{N}\left(s_{1} \mid \sigma_{2}\right) D \geq C$, implying the condition $\lambda \leq \lambda^{*}$, where

$$
\lambda^{*}=\frac{d}{\bar{D}}-1>0
$$

The simple intuition behind this result is that $\mathrm{D} \& \mathrm{O}$ insurance is a means by which the $I$ investors can commit to compensate the agent - satisfy her ex ante participation constraint ${ }^{14}$ - in the event that the short term project turns out badly and she is sued by the $N$-shareholders, even after they themselves have sold their shares and moved on. The insurance bought at $t=0$ represents a commitment to $M$, since it guarantees that she will be indemnified after the $I$-shareholders sell out. An up-front payment to $M$ at $t=0$ would have to be greater than $\bar{D}$, and therefore costlier to the $I$-shareholders, because of $M$ 's risk aversion.

The model suggests also what we should expect to observe in the data if the underlying theory is not to be rejected:

- A necessary condition is that there should exist volatility in the shares of a company, in the sense that its stock prices are driven higher by "good news" which may not reflect the outcome of its "fundamentals".

- The probability of being sued and the amount of damages will be greater, the greater the probability of realisation of the bad state $s=s_{1}$ following publication of the "good news" $\sigma_{2}$ which drives up the share price, and the greater the over-optimism of the $N$-investors. This suggests that the demand for D\&O insurance should be positively related to a company's share price volatility, its susceptibility to good and bad news driving share price fluctuations.

- We must observe a significant change in share ownership, as $I$-investors sell out to $N$-investors.

- Contrary to the hypothesis of Bebchuk and Fried, there is no problem of corporate governance in this model - executives are behaving according to the incentives set for them by

\footnotetext{
${ }^{14}$ It is interesting that when challenged publicly on their policy of buying D\&O insurance, Board Chairmen typically claim that if they did not, they would "not be able to recruit the best people". We would paraphrase that by saying that it is the cheapest way of satisfying their participation constraint.
} 
the board. Under the Bebchuk and Fried theory, the extent of D\&O cover would be a reflection of managers' power to determine their own compensation, and so we would expect it to vary inversely with standard measures of the quality of corporate governance, such as the proportion of independent directors on the board.

We now take the model to the data.

\section{Empirical Analysis}

\subsection{Specification and Data}

We collect data on our two alternative dependent variables, namely a company's D\&O insurance maximum coverage, in year $t\left(\right.$ Coverage $\left._{i t}\right)$ and the insurance premium $\left(\right.$ Premium $\left._{i t}\right)$, from the companies' proxy statements for a panel of Canadian firms, because these are required to disclose whether they purchased D\&O insurance and, if so, to give the details of the policies. ${ }^{15}$ Since the insurance policy contracts are renegotiated only once a year, it is sufficient to focus on annual data.

Each of the two outcome variables (both measured in logs) is, ceteris paribus, a measure of the potential cost and risk of providing insurance to the company concerned. Given the amount of coverage offered, the premium is an indicator of the insurer's estimate of the loss probability. The data collected on premia reflect the actual prices paid for the insurance policy, the total amount paid by the company in the respective year. ${ }^{16}$

We also merge these data with two other panel data-sets which contain useful information on possible explanatory variables determining the outcomes according to the model discussed in the previous section. One of the two external data-sets is BoardEx, which contains information about $\mathrm{CEO}$ and director compensation as well as information on different board characteristics across firms. The key data we are interested in here are the share of independent directors on companies' boards (ShareIndep $i t$ ) and the number of years the directors have been on these boards $\left(\right.$ YearsOnBoard $\left._{i t}\right)$. The other data-set is Compustat, which provides information on companies'

\footnotetext{
${ }^{15}$ Data are publicly available in pdf format at http://www.sedar.com.

${ }^{16}$ We also used the premium coverage ratio as an alternative dependent variable, thus reflecting a company's risk loading, but the results are similar to those based on the insurance premium as a dependent variable, and so we do not report them here for the sake of brevity.
} 
new institutional shareholders $\left(\right.$ NewShareh $\left._{i t}\right)$, the change in the overall number of shareholders between two consecutive years (ChangeShareholders $i t$ ), the fluctuation of the share price (CVPrice $i t)$, and other firm characteristics relevant to the question at stake. These are a company's assets $\left(\right.$ Assets $\left._{i t}\right)$, the return on assets $\left(\right.$ ReturnOnAssets $\left._{i t}\right)$, the market to book value (MarketToBook $\left.{ }_{i t}\right)$ and a company's debt to asset ratio (DebtToAssets $i t$ ). Altogether, 165 Canadian firms bought D\&O insurance for their managers in the years 1996-2008 and are covered in all three data-sets. ${ }^{17}$

According to theory, key fundamentals of the insurance policy outcome are measures of the extent of speculation and the quality of a firm's corporate governance. We aim at capturing a firm's exposure to speculation by the coefficient of variation of the share price of firm $i$ across the months in year $t\left(\right.$ CVPrice $\left._{i t}\right)$.

Our regressions employ the D\&O policy outcome variables and their key drivers. We look at the D\&O insurance policy both from the viewpoint of the model of Bebchuk and Fried (2004) as well as the one of Bolton, Scheinkman, and Xiong (2006). According to Bebchuk and Fried, as pointed out in the Introduction, managerial compensation is part of the agency problem instead of the solution to it. Accordingly, good corporate governance should matter, and thus influence also the extent of D\&O insurance coverage and the contracted premia. ${ }^{18}$ For a given coverage, we would expect premia to be lower, the more independent the directors are, and therefore the better corporate governance is.

We consider an alternative hypothesis in this paper, namely that demand for insurance may be rationalized by the existence of new investors who may sue the manager in case they are not satisfied with the results of past actions in relation to more short-termist projects. For this, we use the fluctuation in the share price as a measure of speculation, and we measure the new shareholders by the number of new institutional shareholders and, alternatively, by the increase in the number of a company's common shareholders between two consecutive years.

Summary statistics on all dependent and independent variables mentioned above are presented in Table I. According to the first block in Table I, the average log coverage is 17.68 (around US $\$ 47 \mathrm{mn}$ ), and exhibits a standard deviation of 1.11 ; the median is 17.73 . The average share of

\footnotetext{
${ }^{17}$ Of all companies in the Canadian data-set, 232 are covered by both Compustat and BoardEx, but roughly one-third of these do not have D\&O insurance.

${ }^{18}$ Independent directors with a longer tenure are assumed to be dependent as they have spent long enough time on the board to have formed strong ties with the company or the CEO. Thus even though de jure they may be independent, de facto they are dependent.
} 
independent directors on the company's board is in all specifications around 84 percent and the mean log of the years an independent director has been on a company's board amounts to around 1.8, which translates into about 6.1 years. The insured companies in the sample have on average 56 new institutional shareholders per year and the average change in the number of shareholders is -0.67 . For both the dependent and the independent variables the variance is smaller than the mean. ${ }^{19}$ According to the second block of Table I, the average log premium amounts to 13.13 (around US\$503,842), the standard deviation and median are 1.21 and 13.13, respectively. ${ }^{20}$

Table II provides summary statistics for the covariates in the sample of non-insured firms. This table furthermore reports the p-values of a t-test about the difference of means and of a $\chi^{2}-$ test about the difference of medians between the sub-samples of insured and non-insured firms. The hypothesis of equal means or equal medians is rejected at conventional levels for some of the control variables $\left(\right.$ CVPrice $_{i t}$, ShareIndep $i t$, YearsOnBoard $i t$ or Assets ${ }_{i t}$ ) as shown by the p-values in the last two columns of Table II, while this does not hold for other covariates (for instance ChangeShareholders $_{i t}$ or MarketToBook $_{i t}$ ). Moreover, we also summarize the evolution of the main control variables over time in Table AI in the Appendix. As the numbers in Table AI show, data for most of our control variables are available for all years in the sample period, whereas data for ShareIndep it and YearsOnBoard $i t$ are available only from 2001 onwards, and data for new institutional shareholders $\left(\right.$ NewShareh $_{i t}$ ) exist only from 2004 onwards. Table AI suggests that the main variables of interest are stable over time.

-Table I and II here -

\footnotetext{
${ }^{19}$ Altogether, we have information on 138 firms in 5 years for which data on coverage, new institutional shareholders share price volatility, and all other control variables are nonmissing simultaneously. The median firm exhibits a positive coverage in less than 3 years. Hence some firms switch in or in and out of insurance coverage during the sample period and some firms have a coverage limit of zero in some years. Therefore, the sample in Model B in Table III, for instance, is based on 388 observations rather than 690 observations when focusing on a positive coverage limit. Estimates of fixed-effects sample selection models suggest that the bias of the parameters of interest due to this potentially systematic sample reduction is negligible, though.

${ }^{20}$ Altogether, we have information on 131 firms in 5 years for which data on premium, new institutional shareholders share price volatility, and all other control variables are nonmissing simultaneously. The median firm exhibits a positive premium in less than 3 years. Therefore, the sample used, for instance, in Model B in Table IV is based on 372 observations rather than 655 observations when focusing on a positive premium.
} 


\subsection{Econometric Model}

This section focuses on an estimation strategy which is suited to estimate the effect of our measures of the quality of corporate governance or the presence of new shareholders and speculation, on the $\mathrm{D} \& \mathrm{O}$ insurance contract's components. We denote the log of the insurance contract outcome of company $i=1, \ldots, N$ in year $t=1996, \ldots, 2008$ by $y_{i t}$. Furthermore, we introduce the row vector of firm-and-time specific covariates $\mathbf{x}_{i t}$ and a conformable column vector of parameters $\beta$ along with a firm fixed effect $\mu_{i}$ and a fixed effect $\lambda_{s t}$ which is specific to sector $s, s=1, \ldots . S$ and year $t .{ }^{21}$ Formally, the log-linear version of the model we estimate may be represented as

$$
y_{i t}=\mathbf{x}_{i t} \beta+\mu_{i}+\lambda_{s t}+\epsilon_{i t} .
$$

$\mathbf{x}_{i t}$ includes the measures of the quality of corporate governance (ShareIndep $i t$ and YearsOnBoard $i t$ ) , the interaction between new shareholders and speculation $\left(\mathrm{NewSh}_{i t} \mathrm{xCVP}_{i t}\right.$ or $\mathrm{ChangeSh}_{i t} \mathrm{xCVP}_{i t}$ respectively), and possible further explanatory variables such as a Assets $_{i t}$, ReturnOnAssets $i t$, MarketToBook $_{i t}$ DebtToAssets $_{i t}$ which we account for in the multivariate analysis. Hence $\mathbf{x}_{i t}=$ $\left[\right.$ ShareIndep $_{i t}$, YearsOnBoard $_{i t}$, NewSh $_{i t} \mathrm{x} C V P_{i t}$ or ChangeSh $_{i t} \mathrm{x} C V P_{i t}$, Assets $_{i t}$, ReturnOnAssets $_{i t}$, MarketToBook $_{i t}$, DebtToAssets $\left.i t\right]$. The fixed effects $\mu_{i}+\lambda_{s t}$ ensure that the parameters on the covariates of interest do not reflect company-specific or sector-time specific effects, which should not be attributed to a firm's corporate governance standards. The latter completely avoids an endogeneity bias of covariates of interest in the respective dimensions of the data.

In the subsequent sections, we present results which are based on variants of the model in equation (6).

\subsection{Empirical Analysis of the Determinants of D\&O Insurance}

Table I summarizes some of the moments of our dependent variables, namely Coverage $i t$ and Premium $_{i t}$. The upper block of Table I provides descriptive statistics for the sample used in the regressions where the log insurance coverage $\left(\right.$ Coverage $\left._{i t}\right)$ is employed as a dependent variable whereas the second block summarizes the moments of the distribution of the sample for which the log in-

\footnotetext{
${ }^{21}$ The latter controls for everything that is specific to a sector and year such as sector-specific cycle effects or trends in $\mathrm{D} \& \mathrm{O}$ insurance which are not directly attributable to firms.
} 
surance premium $\left(\right.$ Premium $\left._{i t}\right)$ is employed as an outcome variable. In addition, Table I displays descriptive statistics for the two measures of the quality of corporate governance, ShareIndep $i t$ and YearsonBoard $_{i t}$, our main explanatory variables which reflect the interaction between speculation and the existence of new shareholders, namely NewSh${ }_{i t} \mathrm{xCVP}_{i t}$ and ChangeSh${ }_{i t} \mathrm{xCVP}_{i t}$ respectively, as well as a number of further controls.

To test whether the extent of $\mathrm{D} \& \mathrm{O}$ insurance is also driven by the existence of new shareholders who have different beliefs than incumbent shareholders, we consider the effects of speculation, measured by the volatility of the share price ${ }^{22}$ as well as its interaction with new shareholders, measured alternatively by NewShareh $i t$ and ChangeShareholders $i t$. Notice that the coverage of the data will vary across specifications so that we report summary statistics for each sample, separately. Key further candidates of determinants of the $\mathrm{D} \& \mathrm{O}$ insurance coverage or the premium are firm variables such as Assets $_{i t}$, as a proxy for size, ReturnOnAssets $s_{i t}$ as a measure of performance, MarketToBook $_{i t}$ as a proxy for a firm's growth opportunities as well as DebtToAssets $i t$ as a measure of financial risk. Their relevance for the dependent variables at stake can be rationalized as follows. Larger companies should have a higher demand for insurance as they face a higher probability of lawsuits than smaller ones (see Boyer, 2003a). Given the higher coverage, the price of the insurance, i.e., the premium, is also expected to be higher (see also Boyer, 2003a). There is no clear-cut hypothesis regarding the contemporaneous effect of the performance measure ReturnOnAssets $s_{i t}$ on outcome. We do however hypothesize that a better past performance should induce a lower D\&O insurance coverage, premium and deductible. ${ }^{23}$

As expected, in most specifications (Model B when using the insurance coverage as a dependent variable and both Models A and B when using the insurance premium as a dependent variable), the effect of a good firm performance in the past has a negative impact on the coverage and the premium. The results are significant at the five or ten percent levels, respectively. Regarding market to book value, we hypothesize, as with Core (1997) that a higher value implies higher coverage and accordingly also higher premia, because the shareholders of such firms want to avoid underinvestment problems. Furthermore, to be able to exploit these growth opportunities, they

\footnotetext{
${ }^{22}$ Stock price volatility is the standard proxy for speculation used in the literature (see for instance Shiller (1981)). We use here the coefficient of variation in the stock price as we consider it to be the most accurate measure.

${ }^{23}$ We infer the latter in Table AII in the Appendix, and consider a specification with the lagged value of ReturnOnAssets ${ }_{i t}$.
} 
expect managers to take more risks in their projects and therefore opt for higher insurance coverage, which effectively induces directors to be less risk averse. The opposite applies for companies with low growth opportunities, where shareholders want managers to behave more carefully and monitor projects more closely, so that they impose more risk on them (see also Core 1997). Lastly, we expect that the higher the debt asset ratio, the higher the implied financial risk of a company, so that the price of the insurance, namely the premium, will be higher.

Table III summarizes the results of a linear model with company and sector-time fixed effects ${ }^{24}$ including the covariates ShareIndep $i t$, YearsOnBoard $i t, \operatorname{NewSh}_{i t} \mathrm{xCVP}_{i t}$ or ChangeSh ${ }_{i t} \mathrm{xCVP}_{i t}$, $\operatorname{respectively}$ Assets $_{i t}$ ReturnOnAssets $_{i t}$, MarketToBook $i t$, DebtToAssets $i t$ contained in $\mathbf{x}_{i t} \cdot{ }^{25}$ As we can see from this table, the coefficients of the interaction terms which are of interest for the hypothesis at stake, namely the combination of new shareholders and speculation, confirm our expectations. As shown by the results for Model A and B in Table III, irrespective of whether we use the number of new institutional shareholders $\left(\mathrm{NewShareh}_{i t}\right)$ or the change in the number of common shareholders (ChangeShareholders $i t$ ), when interacted with our measure of speculation, there is a positive and significant effect on the coverage of insurance purchased by companies. Furthermore, a higher share of independent directors has a positive effect on the D\&O insurance coverage in Model A. The results for ShareIndep $i t$ are significant at the five percent level but only in Model A. This result contradicts the hypothesis inferred from the theory of Bebchuk and Fried (2004), since better corporate governance, proxied by a higher share of independent directors, should ceteris paribus lead to a lower insurance coverage. A company's assets, as a measure of size, have, as would be expected, a positive effect on the amount of insurance coverage and the premium. These results are significant at the one percent level.

-Table III here -

In Table IV, we perform the same type of analysis for the insurance premium. The specification using the interaction between ChangeShareholders $i t$ and CVPrice $_{i t}$, the change in the number of

\footnotetext{
${ }^{24}$ We have also performed a Hausman test to see whether a random effects or fixed effects model is appropriate. The null hypothesis that the random effects model is appropriate is rejected and hence a fixed effects estimator is chosen for estimation.

${ }^{25}$ The company fixed effects capture all possible time-invariant firm attributes such as being listed on the U.S. stock exchange (in the sample period, this is a time-invariant characteristic to the considered firms). Hence, that some companies may also be listed in a country that is more litigious than Canada is controlled for in the regressions through company fixed effects.
} 
shareholders in the presence of speculation has, as expected, a positive effect on the insurance premium. The result is significant at the ten percent level.

-Table IV here -

Thus, our specifications confirm the core hypothesis that the presence of new investors has a positive impact both on the $\mathrm{D} \& \mathrm{O}$ insurance coverage and the $\mathrm{D} \& \mathrm{O}$ insurance premium. Furthermore, larger companies in terms of Assets $_{i t}$ have a higher coverage and insurance premium. These results are once again significant at least at five percent.

\subsection{Sensitivity Analysis}

Given that not all companies decide to purchase D\&O insurance, we assess whether a selective choice of D\&O insurance biases the results. To test for sample selection we follow the approach introduced by Wooldridge (1995) to correct for selection bias with panel data. This approach requires estimating first-stage probit models for each period separately. ${ }^{26}$ The inverse Mills' ratio based on the linear index of the first-stage models serves as a control function in a second-stage regression, where the $\log$ of the coverage limit and the log of the insurance premium are used as dependent variables, respectively. The results of these regressions are sensitivity checks of the results in Tables III and IV and are summarized in Table AIII in the Appendix. Sample selection does not seem to be a problem in the regressions where the log of the coverage limit is employed as a dependent variable as suggested by the insignificant coefficient on the inverse Mills' ratio. Furthermore, the coefficients of our main variables of interest, namely ChangeSh ${ }_{i t} \mathrm{xCVP}_{i t}$ and $\mathrm{NewSh}_{i t} \mathrm{xCVP}_{i t}$ are still positive and significant at least at the five percent level. With log insurance premium as the dependent variable, even though the inverse Mills' ratio is significant at five percent, the coefficient estimates of interest - namely the ones for $\mathrm{ChangeSh}_{i t} \mathrm{xCVP}_{i t}$ and $\mathrm{NewSh}_{i t} \mathrm{xCVP}_{i t}$ - have the same sign and significance as and are quantitatively comparable to their counterparts in Table IV.

\footnotetext{
${ }^{26}$ We utilize the same determinants in the selection and the outcome equations. Often, identification of selection is easier with additional instruments in the selection equation. However, this is not critical here, since the linear index in the selection equation exhibits sufficient variation, whereby identification from nonlinearity is possible. Moreover, with panel data and time-varying coefficients in the selection equations, the need of outside instruments is further reduced relative to cross-sectional approaches to sample selection.
} 
As suggested by Core (2000), the insurance premium may also depend on excess coverage purchased, which can be measured as the residual to a regression which expresses the log coverage limit in terms of the dependent variables as presented in Table III. The rationale for including excess coverage as an explanatory variable of log insurance premium is that it captures information that is orthogonal to the other determinants of the insurance premium. Coverage limit exhibits discontinuities at discrete multiples of US\$5 mn. These discontinuities may contain information that has an impact on the insurance premium. The results of these regressions which include as an additional control the residual coverage limit, AbnCovLimit $i t$, are summarized in Table AIV in the Appendix. As the numbers in Table AIV show, the coefficient of AbnCovLimitit is positive and significant which is in line with the results in Core (2000). The coefficients of our main variables of interest, ChangeSh ${ }_{i t} \mathrm{xCVP}_{i t}$ and $\mathrm{NewSh}_{i t} \mathrm{xCVP}_{i t}$, are equivalent in sign and magnitude to their counterparts in the baseline regressions presented in Table IV. Hence, excluding the excess coverage limit from the model does not bias the results of primary interest to this paper.

Finally, we add a number of additional control variables which can also influence the demand for D\&O insurance, following Core (1997). We gather this additional information from the companies' annual reports, annual information forms, management circular or proxy information from SEDAR. The potential candidates considered are presented in the following. LitDisc ${ }_{i t}$ is a binary indicator variable equal to one if the company discloses pending or higher litigation in its annual reports, and zero otherwise. According to Core (1997), we expect firms that exhibit pending litigation to display a higher litigation risk because of negative effects on reputation or because litigation may induce higher $\mathrm{D} \& \mathrm{O}$ claims. InsValue $i t$ represents insider ownership measured as the share of the company's total common shares outstanding owned by inside directors. We do not have a clear-cut expectation of the effect of this variable on the demand for insurance coverage for two reasons. On the one hand, the better alignment of incentives may be negatively correlated to the insurance coverage whereas, on the other hand, under the risk aversion hypothesis a higher share of insider ownership may imply a higher demand for D\&O insurance. Since D\&O claims may also result from divestitures, Core (1997) suggests controlling for whether the company sold substantial assets or divested a business. Hence, we consider an additional indicator variable Divestor ${ }_{i t}$ which equals one if the firms displayed in its reports income from discontinued operations and special items exceeding $3 \%$ of total assets, and zero otherwise. Finally, we employ a measure of excessive 
director compensation ExcessPay $i t$. This variable is constructed as the standardized residual from a weighted least squares regression of director pay on possible determinants. ${ }^{27}$ Notice that company fixed effects capture whether the company is a utility or not and whether it is listed on a US exchange as well or not, since these characteristics are time-invariant in the data at hand.

The results of these robustness checks are summarized in Table AV in the Appendix. As the numbers in Table AV show, the coefficient estimates of interest - namely the ones for ChangeSh ${ }_{i t} \mathrm{xCVP}_{i t}$ and $\mathrm{NewSh}_{i t} \mathrm{xCVP}$ it - have the same sign and significance as and are quantitatively comparable to their counterparts in Table III. The same applies to the regression results where the insurance premium is used as a dependent variable. Once again, the coefficients of the main variables of interest are similar in sign and magnitude to their counterparts in Table IV. Hence, excluding these further control variables does not bias the estimates of interest to this paper.

\section{Conclusion}

This paper is concerned with analyzing so-called "Directors' and Officers'" (D\&O) insurance. The purpose is to gain a better understanding of the raison d'être for this insurance market, at least in the case of listed companies. Applying the framework of the model introduced by Bolton, Scheinkman, and Xiong (2006) allows us to reinterpret the role of D\&O insurance. If managers act in line with incentives designed to promote the interest of initial shareholders when they take decisions that encourage short-term overvaluation of the firm's shares, this can strictly speaking not be labeled as a failure of corporate governance. Furthermore, we also shed light on the empirical support that can be given to this theoretical approach, by testing whether not only the characteristics of corporate governance, but also the existence of new shareholders and volatile markets, influence the demand for and supply of $\mathrm{D} \& \mathrm{O}$ insurance. Using a panel of 232 Canadian companies for the years 1996 to 2008, our results suggest that the existence of new shareholders in the presence of

\footnotetext{
${ }^{27}$ We follow Core (1997) closely and assume that director compensation is a function of firm-specific covariates, proxies for firm risk and stock ownership. Firm-specific variables considered are the firm assets (Assets $i t)$, the market value of equity, both measured in logs, a proxy for growth opportunities defined as sum of the firm's liabilities and market value of equity divided by the book value of assets. Firm risk is measured by the annualized volatility of the daily compounded return for the prior year and by a dummy variable which shows whether the company is also listed in the US. Finally, director compensation is also a function of inside ownership (InsValue $i t$ ) and a dummy variable which equals one if directors were also awarded stock grants or options. Furthermore, we follow the same weighted least square estimation procedure where weights have been computed in the same way as in Core (1997) Table 2, p. 75 to compute the standardized residuals as proxies for excessive executive compensation.
} 
volatility leads to an increase in the amount of $\mathrm{D} \& \mathrm{O}$ insurance coverage purchased by companies, consistent with the idea that if senior executives are to be given the incentives to use such volatility to make short run gains in share prices, they must be insured against the adverse consequences of their doing so.

The empirical results also suggest some conclusions for public policy toward the D\&O insurance market. In the first place, as we suggested in Section 2, the concern that the availability of D\&O insurance creates a moral hazard problem does not seem justified: asymmetric information in the form of a moral hazard problem does not appear to be significant and this form of insurance does not seem to be positively associated with standard measures of bad corporate governance. Our results are robust to a host of sensitiviy checks, by means of including additional control variables or testing for sample selection.

However, the theory and empirical results in this paper do suggest a new concern: D\&O insurance does provide a convenient instrument for initial owners of a company to take advantage of short term bubbles and differences in beliefs of insiders and outsiders in capital markets in the way modelled by Bolton, Scheinkman, and Xiong. Note that it is not the function of the D\&O insurers to decide whether decisions are being taken in the long-term interests of the company, but rather to evaluate the probability of and likely costs arising from litigation, and provided they have the information to do this and set premia accordingly, they are happy to take the business. Corresponding diversion of resources into short-term investments that may worsen the long-run performance of a company, and the costs associated with the litigation that may result, are however real resource costs to the economy rather than just redistributions among shareholders. At the same time, one cannot blame the D\&O market for the existence of the preconditions that favour its use, and, given that much of the insurance is bought by companies that are not subject to stock price volatility, and for which therefore the hypothesis proposed and tested in this paper does not apply, it is arguable that the appropriate policy solution is to address the more fundamental aspects of capital market failure.

\section{References}

[1] Bebchuk, Lucian and Jesse Fried, 2004, Pay Without Performance: The Unfulfilled Promise of Executive Compensation (Harvard University Press, Cambridge (MA)). 
[2] Bhagat, Sanjai, James A. Brickley and Jeffrey L. Coles, Managerial Indemnification and Liability Insurance: The Effect on Shareholder Wealth, 1987, The Journal of Risk and Insurance 54(4), 721-736.

[3] Bolton, Patrick, José Scheinkman and Wei Xiong, 2006, Executive Compensation and ShortTermist Behavior in Speculative Markets, Review of Economic Studies 73, 577-610.

[4] Boyer, Martin M., 2003a, Is the Demand for Corporate Insurance a Habit? Evidence from Directors' and Officers' Insurance, CIRANO Scientific Series, No.2003s-42.

[5] Boyer, Martin M., 2003b, Directors' and Officers' Insurance and Shareholders' Protection, CIRANO Scientific Series, No. 2003s-64.

[6] Boyer, Martin, M. and Lea H. Stern, 2012, Is Corporate Governance Risk Valued? Evidence from Directors' and Officers' Insurance, Journal of Corporate Finance, 18, 349-372.

[7] Cao, Zhiyan and Ganapathi S. Narayanamoorthy, 2011, The Effect of Litigation Risk on Management Earnings Forecasts, Contemporary Accounting Research, 28(1), 125-173.

[8] Chalmers, John M.R., Larry Y. Dann and Jarrad Harford, 2002, Managerial Opportunism? Evidence From Directors' and Officers' Insurance Purchases, The Journal of Finance 57(2), 609-636.

[9] Core, John E. , 1997, On the Corporate Demand for Directors' and Officers' Insurance, The Journal of Risk and Insurance 64(1), 63-87.

[10] Core, John E. , 2000, The Directors' and Officers' Insurance Premium: An Outside Assessment of the Quality of Corporate Governance, The Journal of Law, Economics and Organization 16 (2), 449-477.

[11] GenRe - Kölnische Rückversicherungs-Gesellschaft AG, 2005, Loss and Litigation Report: The New Spotlight on Directors \& Officers in the EU, Cologne.

[12] Grossman, Sanford J. and Oliver D. Hart, 1983, An Analysis of the Principal Agent Problem, Econometrica 51(1), 7-45.

[13] Gupta, Manu and Puneet Prakash, 2012, Information Embedded in Directors and Officers Insurance Purchases, The Geneva Papers, 37, 429-451.

[14] Gutierrez, Maria, 2003, An Economic Analysis of Corporate Directors' Fiduciary Duties, The RAND Journal of Economics 34(3), 516-535.

[15] Lin, Chen, Micah S. Officer and Hong Zou, 2011, Directors' and Officers' Liability Insurance and Acquisition Outcomes, Journal of Financial Economics, 102, 507-525.

[16] O'Sullivan, Noel, 1997, Insuring the Agents: The Role of Directors' and Officers' Insurance in Corporate Governance, The Journal of Risk and Insurance, 64, 545-556.

[17] Parry, Mark E. and Arthur E. Parry,1991, The Purchase of Insurance by a Risk-Neutral Firm for a Risk-Averse Agent, The Journal of Risk and Insurance 58(1), 30-46.

[18] Ryan Ellen M. and Laura E. Simmons, 2008, Securities Class Action Settlements: 2008 Review and Analysis, Stanford Law School, Securities Class Action Clearinghouse, http://securities.stanford.edu/Settlements/REVIEW_19952008/Settlements_Through_12_2008.pdf 
[19] Shiller, Robert J., 1981, Do Stock Prices Move Too Much to be Justified by Subsequent Changes in Dividends?, The American Economic Review 71(3), 421-436.

[20] The Economist, 2003, Double Indemnity: Company Executives Should Pay for Their Own Mistakes, http://www.economist.com/node/1842530, found 24.03.2011

[21] Towers Watson, 2009, Directors and Officers Liability: 2008 Survey of Insurance Purchasing Trends, http://www.towerswatson.com/assets/pdf/2791/2791.pdf (found January, 26st, 2011)

[22] Wooldridge, Jeffrey M., 1995, Selection Corrections for Panel Data Models Under Conditional Mean Independence Assumptions, Journal of Econometrics, 68, 115-132.

\section{APPENDIX - TABLES}

-Table AI here-

-Table AII here-

-Table AIII here-

-Table AIV here-

-Table AV here- 





Table II - Linear models with company and sector year fixed effects (augmented models)

(Dependent variable is the log of insurance coverage limit in year $\mathrm{t}$ )

\begin{tabular}{|c|c|c|c|}
\hline Variable & Acronym & Model A & Model B \\
\hline \multirow[t]{2}{*}{ Interaction Term Between ChangeShareholders ${ }_{i t}$ and CVPrice ${ }_{i t}$} & ChangeSh_CVP it & $0.455^{\star *}$ & - \\
\hline & & 0.210 & - \\
\hline \multirow{2}{*}{ Interaction Term Between NewShareh ${ }_{i t}$ and CVPrice $_{i t}$} & NewSh_CVP it & - & $0.612^{\star \star *}$ \\
\hline & & - & 0.196 \\
\hline \multirow[t]{2}{*}{ Change in the Number of Common Shareholders Between Years t and t-1 } & ChangeShareholders $_{\text {it }}$ & $-0.079 \star \star$ & - \\
\hline & & 0.035 & - \\
\hline \multirow[t]{2}{*}{ Log Number of New Institutional Shareholders in Year t } & NewShareh $_{\text {it }}$ & - & 0.046 \\
\hline & & - & 0.072 \\
\hline \multirow[t]{2}{*}{ Coefficient of Variation of the Share Price for Year $t$} & CVPrice $_{i t}$ & $0.836^{\star \star *}$ & $-1.722^{\star \star}$ \\
\hline & & 0.270 & 0.771 \\
\hline \multirow[t]{2}{*}{ Share of Independent Directors in the Company's Total Directors in percent in Year t } & Sharelndep $_{\text {it }}$ & $0.011^{\star *}$ & 0.006 \\
\hline & & 0.004 & 0.005 \\
\hline \multirow{2}{*}{ Log of Independent Directors' Years on Company's Board in Year t } & YearsOnBoard ${ }_{\text {it }}$ & 0.096 & 0.047 \\
\hline & & 0.091 & 0.099 \\
\hline \multirow[t]{2}{*}{ Log of Company' s Total Assets for Year t } & Assets $_{\text {it }}$ & $0.334^{\star \star \star}$ & $0.274^{\star \star \star}$ \\
\hline & & 0.056 & 0.075 \\
\hline \multirow[t]{2}{*}{ Company's Return on Assets for Year t } & ReturnOnAssets ${ }_{\text {it }}$ & 0.003 & $0.008^{\star * *}$ \\
\hline & & 0.003 & 0.003 \\
\hline \multirow[t]{2}{*}{ Company's Market to Book Ratio for Year t } & MarketToBook $_{\text {it }}$ & -0.002 & 0.002 \\
\hline & & 0.004 & 0.004 \\
\hline \multirow[t]{2}{*}{ Company's Debt Asset Ratio for Year t } & DebtToAssets $_{\text {it }}$ & -0.414 & 0.338 \\
\hline & & 0.280 & 0.375 \\
\hline Observations & & 436 & 388 \\
\hline Adj. $R^{2}$ & & 0.989 & 0.985 \\
\hline Within $\mathrm{R}^{2}$ & & 0.711 & 0.694 \\
\hline
\end{tabular}

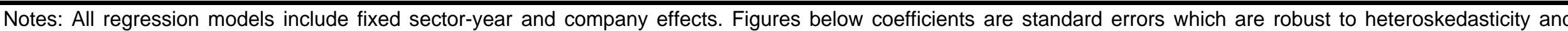
autocorrelation. ${ }^{* \star *},{ }^{\star *},{ }^{*}$ indicate statistical significance at 1,5 , and 10 percent, respectively (using two-tailed test statistics). 
Table III - Linear models with company and sector year fixed effects (augmented models)

(Dependent variable is the log of insurance coverage limit in year $t$ )

\begin{tabular}{|c|c|c|c|}
\hline Variable & Acronym & Model A & Model B \\
\hline \multirow[t]{2}{*}{ Interaction Term Between ChangeShareholders ${ }_{i t}$ and CVPrice ${ }_{i t}$} & ChangeSh $_{\text {it }} \times \mathrm{CVP}_{\text {it }}$ & $0.455^{\star *}$ & - \\
\hline & & 0.210 & - \\
\hline \multirow{2}{*}{ Interaction Term Between NewShareh ${ }_{i t}$ and CVPrice $_{i t}$} & $\mathrm{NewSh}_{\mathrm{it}} \mathrm{xCVP} \mathrm{P}_{\mathrm{it}}$ & - & $0.612^{\star \star *}$ \\
\hline & & - & 0.196 \\
\hline \multirow[t]{2}{*}{ Change in the Number of Common Shareholders Between Years t and t-1 } & ChangeShareholders $_{\text {it }}$ & $-0.079 \star \star$ & - \\
\hline & & 0.035 & - \\
\hline \multirow[t]{2}{*}{ Log Number of New Institutional Shareholders in Year t } & NewShareh $_{\text {it }}$ & - & 0.046 \\
\hline & & - & 0.072 \\
\hline \multirow[t]{2}{*}{ Coefficient of Variation of the Share Price for Year $t$} & CVPrice $_{i t}$ & $0.836^{\star \star *}$ & $-1.722^{\star \star}$ \\
\hline & & 0.270 & 0.771 \\
\hline \multirow[t]{2}{*}{ Share of Independent Directors in the Company's Total Directors in percent in Year t } & Sharelndep $_{\text {it }}$ & $0.011^{\star *}$ & 0.006 \\
\hline & & 0.004 & 0.005 \\
\hline \multirow{2}{*}{ Log of Independent Directors' Years on Company's Board in Year t } & YearsOnBoard ${ }_{\text {it }}$ & 0.096 & 0.047 \\
\hline & & 0.091 & 0.099 \\
\hline \multirow[t]{2}{*}{ Log of Company' s Total Assets for Year t } & Assets $_{\text {it }}$ & $0.334^{\star \star \star}$ & $0.274^{\star \star \star}$ \\
\hline & & 0.056 & 0.075 \\
\hline \multirow[t]{2}{*}{ Company's Return on Assets for Year t } & ReturnOnAssets ${ }_{\text {it }}$ & 0.003 & $0.008^{\star * *}$ \\
\hline & & 0.003 & 0.003 \\
\hline \multirow[t]{2}{*}{ Company's Market to Book Ratio for Year t } & MarketToBook $_{\text {it }}$ & -0.002 & 0.002 \\
\hline & & 0.004 & 0.004 \\
\hline \multirow[t]{2}{*}{ Company's Debt Asset Ratio for Year t } & DebtToAssets $_{\text {it }}$ & -0.414 & 0.338 \\
\hline & & 0.280 & 0.375 \\
\hline Observations & & 436 & 388 \\
\hline Adj. $R^{2}$ & & 0.989 & 0.985 \\
\hline Within $\mathrm{R}^{2}$ & & 0.711 & 0.694 \\
\hline
\end{tabular}

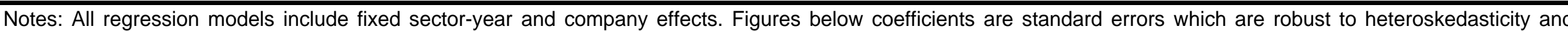
autocorrelation. ${ }^{* \star *},{ }^{\star *},{ }^{*}$ indicate statistical significance at 1,5 , and 10 percent, respectively (using two-tailed test statistics). 
Table IV - Linear models with sector-year and company fixed effects (augmented models)

(Dependent variable is the log insurance premium in year $\mathrm{t}$ )

\begin{tabular}{|c|c|c|c|}
\hline Variable & Acronym & Model A & Model B \\
\hline \multirow{2}{*}{ Interaction Term Between ChangeShareholders ${ }_{i t}$ and CVPrice $_{i t}$} & ChangeSh $_{i t} x C V P_{i t}$ & $0.585^{\star}$ & - \\
\hline & & 0.318 & - \\
\hline \multirow[t]{2}{*}{ Interaction Term Between NewShareh ${ }_{\mathrm{it}}$ and CVPrice $\mathrm{it}_{\mathrm{it}}$} & $\mathrm{NewSh}_{\mathrm{it}} \times \mathrm{XVP}_{\mathrm{it}}$ & - & -0.238 \\
\hline & & - & 0.252 \\
\hline \multirow[t]{2}{*}{ Change in the Number of Common Shareholders Between Years t and t-1 } & ChangeShareholders $_{\text {it }}$ & $-0.100 *$ & - \\
\hline & & 0.053 & - \\
\hline \multirow[t]{2}{*}{ Log Number of New Institutional Shareholders in Year t } & NewShareh $_{\text {it }}$ & - & $0.166^{\star}$ \\
\hline & & - & 0.089 \\
\hline \multirow[t]{2}{*}{ Coefficient of Variation of the Share Price for Year $t$} & CVPrice $_{i t}$ & 0.479 & 1.475 \\
\hline & & 0.424 & 0.953 \\
\hline \multirow[t]{2}{*}{ Share of Independent Directors in the Company's Total Directors in percent in Year t } & Sharelndep $_{\text {it }}$ & -0.005 & 0.009 \\
\hline & & 0.007 & 0.006 \\
\hline \multirow[t]{2}{*}{ Log of Independent Directors' Years on Company's Board in Year t } & YearsonBoard $_{\text {it }}$ & -0.097 & -0.026 \\
\hline & & 0.141 & 0.123 \\
\hline \multirow[t]{2}{*}{ Log of Company' s Total Assets for Year t } & Assets $_{\text {it }}$ & $0.349 * \star \star$ & $0.242^{\star \star}$ \\
\hline & & 0.087 & 0.094 \\
\hline \multirow[t]{2}{*}{ Company's Return on Assets for Year t } & ReturnOnAssets $_{\text {it }}$ & 0.005 & 0.000 \\
\hline & & 0.004 & 0.004 \\
\hline \multirow[t]{2}{*}{ Company's Market to Book Ratio for Year t } & MarketToBook $\mathrm{it}_{\mathrm{t}}$ & 0.001 & -0.003 \\
\hline & & 0.006 & 0.005 \\
\hline \multirow[t]{2}{*}{ Company's Debt Asset Ratio for Year t } & DebtToAssets $_{\text {it }}$ & 0.003 & -0.537 \\
\hline & & 0.441 & 0.463 \\
\hline Observations & & 418 & 372 \\
\hline Adj. $R^{2}$ & & 0.908 & 0.938 \\
\hline Within $\mathrm{R}^{2}$ & & 0.754 & 0.644 \\
\hline
\end{tabular}

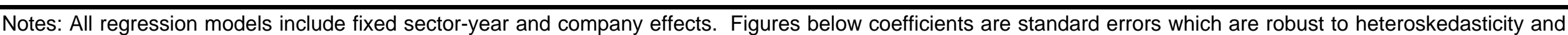
autocorrelation ${ }^{\star \star *},{ }^{\star *}, *$ indicate statistical significance at 1, 5, and 10 percent, respectively (using two-tailed test statistics). 


\begin{tabular}{|c|c|c|c|c|c|c|c|c|c|c|c|c|c|c|}
\hline Variable & Acronym & 1996 & 1997 & 1998 & 1999 & 2000 & 2001 & 2002 & 2003 & 2004 & 2005 & 2006 & 2007 & 2008 \\
\hline \multicolumn{15}{|l|}{ Insured firms } \\
\hline Log of Coverage Limit of the Insurance Policy for Year t & Coverage $_{\text {it }}$ & 16.851 & 16.876 & 16.962 & 17.146 & 17.229 & 17.458 & 17.375 & 17.352 & 17.422 & 17.460 & 17.465 & 17.507 & 17.646 \\
\hline Log of a Company's Insurance Premium for Year t & Premium $_{\text {it }}$ & 11.195 & 11.233 & 11.278 & 11.331 & 11.424 & 11.639 & 11.851 & 12.310 & 12.804 & 12.898 & 12.908 & 12.861 & 12.868 \\
\hline Log of a Company's Insurance Deductible for Year t & Deductible $_{\text {it }}$ & 12.144 & 12.015 & 11.783 & 11.882 & 11.922 & 11.950 & 12.069 & 12.435 & 12.811 & 12.807 & 12.869 & 12.793 & 12.809 \\
\hline Interaction Term Between ChangeShareholders ${ }_{i t}$ and CVPrice $_{i t}$ & ChangeSh $_{\text {it }} \times \mathrm{CVP}_{\mathrm{it}}$ & & -0.018 & 0.006 & -0.003 & 0.584 & -0.021 & -0.829 & -0.426 & 0.019 & -0.002 & 0.169 & -0.029 & 0.054 \\
\hline Interaction Term Between NewShareh $_{\text {it }}$ and CVPrice ${ }_{i t}$ & $\mathrm{NewSh}_{\mathrm{it}} \mathrm{xCVP_{it }}$ & - & - & - & - & - & - & - & - & 0.519 & 0.459 & 0.418 & 0.483 & 0.876 \\
\hline Change in the Number of Common Shareholders Between Years $t$ and $t-1$ & ChangeShareholders $_{i t}$ & & -0.134 & 0.006 & -0.078 & 4.983 & -0.032 & -3.706 & -1.843 & 0.010 & -0.011 & 0.997 & -0.163 & 0.045 \\
\hline Log Number of New Institutional Shareholders in Year t & NewShareh $_{\text {it }}$ & - & - & - & - & - & - & - & - & 4.382 & 3.515 & 3.581 & 3.733 & 3.583 \\
\hline Coefficient of Variation of the Share Price for Year $t$ & CVPrice $_{\text {it }}$ & 0.122 & 0.173 & 0.182 & 0.162 & 0.182 & 0.169 & 0.168 & 0.164 & 0.122 & 0.127 & 0.118 & 0.131 & 0.269 \\
\hline Share of Independent Directors in the Company's Total Directors in percent in Year t & Sharelndep $_{\text {it }}$ & - & - & - & - & - & 80.594 & 80.964 & 84.720 & 82.762 & 84.058 & 83.562 & 84.120 & 81.115 \\
\hline Log of Independent Directors' Years on Company's Board in Year t & YearsOnBoard $_{\text {it }}$ & - & - & - & - & - & 1.922 & 1.315 & 1.699 & 1.751 & 1.766 & 1.741 & 1.785 & 1.711 \\
\hline Log of Company's Total Assets for Year t & Assets $_{i t}$ & 7.036 & 6.816 & 6.796 & 6.954 & 7.237 & 7.426 & 7.238 & 7.291 & 7.494 & 7.491 & 7.610 & 7.660 & 7.880 \\
\hline Company's Return on Assets for Year t & ReturnOnAssets $_{\text {it }}$ & 3.015 & -1.716 & -0.919 & 1.285 & 1.253 & -4.461 & -3.726 & -2.291 & -1.188 & -4.089 & -1.714 & -1.784 & -10.868 \\
\hline Company's Market to Book Ratio for Year t & MarketToBook $_{\text {it }}$ & - & - & 2.683 & 2.365 & 2.013 & 2.576 & 1.996 & 2.440 & 2.678 & 2.866 & 3.416 & 3.040 & 1.436 \\
\hline Company's Debt Assets Ratio for Year t & DebtToAssets $_{\text {it }}$ & 0.237 & 0.247 & 0.254 & 0.242 & 0.229 & 0.244 & 0.221 & 0.196 & 0.194 & 0.196 & 0.202 & 0.197 & 0.244 \\
\hline \multicolumn{15}{|l|}{ Non-insured firms } \\
\hline Log of Coverage Limit of the Insurance Policy for Year $t$ & Coverage $_{\text {it }}$ & - & - & - & - & - & - & - & - & - & - & - & - & - \\
\hline Log of a Company's Insurance Premium for Year $\mathrm{t}$ & Premium $_{\text {it }}$ & - & - & - & - & - & - & - & - & - & - & - & - & - \\
\hline Log of a Company's Insurance Deductible for Year t & Deductible $_{\text {it }}$ & - & - & - & - & - & - & - & - & - & - & - & - & - \\
\hline Interaction Term Between ChangeShareholders ${ }_{i t}$ and CVPrice $_{i t}$ & ChangeSh $_{\text {it }} \times \mathrm{CVP}_{\mathrm{it}}$ & - & 0.013 & -1.674 & 0.000 & 0.000 & 0.001 & 0.000 & 0.030 & -0.002 & -0.002 & 0.009 & -0.002 & 0.039 \\
\hline Interaction Term Between NewShareh $_{\text {it }}$ and CVPrice ${ }_{i t}$ & $\mathrm{NewSh}_{\mathrm{it}} \mathrm{xCVP} \mathrm{P}_{\mathrm{it}}$ & - & - & - & - & - & - & - & - & 0.696 & 0.557 & 0.522 & 0.560 & 0.974 \\
\hline Change in the Number of Common Shareholders Between Years $t$ and $t-1$ & ChangeShareholders $_{\text {it }}$ & - & 0.163 & -8.858 & 0.000 & 0.000 & 0.009 & -0.001 & 0.017 & -0.004 & -0.003 & 0.021 & -0.006 & 0.028 \\
\hline Log Number of New Institutional Shareholders in Year t & NewShareh $_{\text {it }}$ & - & - & - & - & - & - & - & - & 3.398 & 2.976 & 3.225 & 3.321 & 2.990 \\
\hline Coefficient of Variation of the Share Price for Year $t$ & CVPrice $_{\text {it }}$ & 0.224 & 0.119 & 0.142 & 0.102 & 0.259 & 0.251 & 0.238 & 0.237 & 0.191 & 0.177 & 0.176 & 0.180 & 0.337 \\
\hline Share of Independent Directors in the Company's Total Directors in percent in Year t & Sharelndep $_{\text {it }}$ & - & - & - & - & - & 93.333 & 93.333 & 77.929 & 75.411 & 77.735 & 79.352 & 78.636 & 78.572 \\
\hline Log of Independent Directors' Years on Company's Board in Year t & YearsOnBoard $_{\mathrm{it}}$ & - & - & - & - & - & 0.262 & 0.833 & 1.552 & 1.434 & 1.430 & 1.555 & 1.659 & 1.244 \\
\hline Log of Company's Total Assets for Year t & Assets $_{\mathrm{it}}$ & 9.090 & 9.226 & 10.585 & 9.234 & 8.075 & 8.439 & 8.555 & 6.842 & 5.560 & 5.406 & 5.859 & 6.043 & 6.237 \\
\hline Company's Return on Assets for Year t & ReturnOnAssets $_{\text {it }}$ & 2.521 & 4.374 & 0.983 & 3.104 & 3.545 & 3.636 & 4.402 & 1.867 & -6.763 & -8.788 & -8.950 & -3.388 & -10.776 \\
\hline Company's Market to Book Ratio for Year t & MarketToBook $_{\text {it }}$ & - & - & 1.786 & 1.276 & 1.491 & 1.861 & 1.907 & 4.793 & 5.402 & 3.478 & 3.111 & 2.494 & 1.484 \\
\hline Company's Debt Assets Ratio for Year t & DebtToAssets $_{\text {it }}$ & 0.395 & 0.401 & 0.401 & 0.466 & 0.418 & 0.338 & 0.358 & 0.178 & 0.138 & 0.176 & 0.166 & 0.164 & 0.168 \\
\hline
\end{tabular}


Table All - Linear models with sector-year and company fixed effects (augmented models)

\begin{tabular}{|c|c|c|c|c|c|}
\hline \multirow[b]{2}{*}{ Variable } & \multirow[b]{2}{*}{ Acronym } & \multicolumn{2}{|c|}{$\begin{array}{l}\text { Log of Coverage Limit as a } \\
\text { dependent variable }\end{array}$} & \multicolumn{2}{|c|}{$\begin{array}{l}\text { Log of Insurance Premium as a } \\
\text { dependent variable }\end{array}$} \\
\hline & & Model A & Model B & Model A & Model B \\
\hline \multirow{2}{*}{ Interaction Term Between ChangeShareholders ${ }_{\text {it }}$ and CVPrice ${ }_{i t}$} & ${\text { Change } S h_{i t} \times C V P_{i t}}$ & $0.470^{\star \star}$ & - & $0.640^{*}$ & - \\
\hline & & 0.213 & - & 0.326 & - \\
\hline \multirow[t]{2}{*}{ Interaction Term Between NewShareh ${ }_{\text {it }}$ and CVPrice ${ }_{\text {it }}$} & $\mathrm{NewSh}_{\mathrm{i}} \mathrm{XCVP}$ it & - & $0.477^{* *}$ & - & -0.199 \\
\hline & & - & 0.204 & - & 0.243 \\
\hline \multirow[t]{2}{*}{ Change in the Number of Common Shareholders Between Years $t$ and $t-1$} & ChangeShareholders ${ }_{\mathrm{it}}$ & $-0.081^{\star *}$ & - & $-0.108^{*}$ & - \\
\hline & & 0.036 & - & 0.055 & - \\
\hline \multirow[t]{2}{*}{ Log Number of New Institutional Shareholders in Year $\mathrm{t}$} & NewShareh $_{\text {it }}$ & - & 0.091 & - & $0.181^{*}$ \\
\hline & & - & 0.077 & - & 0.094 \\
\hline \multirow[t]{2}{*}{ Coefficient of Variation of the Share Price for Year $t$} & CVPrice $_{\text {it }}$ & $0.933^{\star \star \star}$ & -1.083 & 0.578 & 1.394 \\
\hline & & 0.270 & 0.795 & 0.424 & 0.948 \\
\hline \multirow[t]{2}{*}{ Share of Independent Directors in the Company's Total Directors in percent in Year $t$} & Sharelndep $_{\text {it }}$ & $0.012^{\star \star \star}$ & 0.008 & -0.009 & 0.007 \\
\hline & & 0.005 & 0.005 & 0.007 & 0.006 \\
\hline \multirow[t]{2}{*}{ Log of Independent Directors' Years on Company's Board in Year t } & YearsOnBoard $_{\text {it }}$ & 0.158 & 0.185 & 0.027 & 0.114 \\
\hline & & 0.104 & 0.120 & 0.161 & 0.143 \\
\hline \multirow[t]{2}{*}{ Log of Company's Total Assets for Year t } & Assets $_{i t}$ & $0.324^{\star \star \star}$ & $0.263^{\star \star *}$ & $0.367^{\star \star \star}$ & $0.246^{\star \star}$ \\
\hline & & 0.059 & 0.081 & 0.091 & 0.097 \\
\hline \multirow[t]{2}{*}{ Lag of Company's Return on Assets } & Lag_ReturnonAssets $_{i t}$ & -0.001 & $-0.004^{*}$ & $-0.008^{\star \star}$ & $-0.008^{\star \star}$ \\
\hline & & 0.002 & 0.003 & 0.004 & 0.003 \\
\hline \multirow[t]{2}{*}{ Company's Market to Book Ratio for Year t } & MarketToBook $_{\mathrm{it}}$ & -0.009 & -0.013 & -0.005 & $-0.017 *$ \\
\hline & & 0.008 & 0.008 & 0.012 & 0.010 \\
\hline \multirow[t]{2}{*}{ Company's Debt Asset Ratio for Year t } & DebttoAssets $_{\text {it }}$ & -0.468 & 0.035 & -0.335 & $-0.900^{*}$ \\
\hline & & 0.293 & 0.389 & 0.467 & 0.468 \\
\hline Observations & & 416 & 367 & 400 & 353 \\
\hline Adj. $R^{2}$ & & 0.951 & 0.947 & 0.908 & 0.944 \\
\hline
\end{tabular}


Table Alll - Testing for sample selection

\begin{tabular}{|c|c|c|c|c|c|}
\hline \multirow[t]{2}{*}{ Variable } & \multirow[t]{2}{*}{ Acronym } & \multicolumn{2}{|c|}{$\begin{array}{l}\text { Log Coverage as a } \\
\text { dependent variable }\end{array}$} & \multicolumn{2}{|c|}{$\begin{array}{l}\text { Log Premium as a } \\
\text { dependent variable }\end{array}$} \\
\hline & & Model A & Model B & Model A & Model B \\
\hline \multirow{2}{*}{ Interaction Term Between ChangeShareholders ${ }_{i t}$ and CVPrice $_{i t}$} & Change Sh $_{i t} \times C V P_{i t}$ & $0.513^{\star \star}$ & & $0.572^{\star *}$ & \\
\hline & & 0.238 & & 0.282 & \\
\hline \multirow[t]{2}{*}{ Interaction Term Between NewShareh ${ }_{i t}$ and CVPrice $_{i t}$} & $\mathrm{NewSh}_{\mathrm{it}} \mathrm{xCVP}$ it & & $0.603^{\star \star \star}$ & & -0.263 \\
\hline & & & 0.196 & & 0.239 \\
\hline \multirow[t]{2}{*}{ Change in the Number of Common Shareholders Between Years t and t-1 } & ChangeShareholders $_{\text {it }}$ & $-0.089^{* *}$ & & $-0.098^{\star *}$ & \\
\hline & & 0.040 & & 0.047 & \\
\hline \multirow[t]{2}{*}{ Log Number of New Institutional Shareholders in Year t } & NewShareh $_{\text {it }}$ & & 0.025 & & 0.128 \\
\hline & & & 0.074 & & 0.09 \\
\hline \multirow[t]{2}{*}{ Coefficient of Variation of the Share Price for Year $t$} & CVPrice $_{\text {it }}$ & $0.675^{\star \star}$ & $-1.623^{\star *}$ & $0.947^{\star \star}$ & $1.72^{\star *}$ \\
\hline & & 0.324 & 0.774 & 0.389 & 0.948 \\
\hline \multirow[t]{2}{*}{ Inverse Mills Ratio } & InvMills $_{\text {it }}$ & -0.141 & -0.165 & $-0.388^{\star \star}$ & $-0.341^{\star *}$ \\
\hline & & 0.147 & 0.129 & 0.178 & 0.16 \\
\hline Observations & & 389 & 389 & 372 & 372 \\
\hline Adj. $R^{2}$ & & 0.949 & 0.951 & 0.945 & 0.945 \\
\hline
\end{tabular}

Notes: All regression models include fixed sector-year and company effects. We also control in all four regressions for Sharelndep ${ }_{i t}$, YearsOnBoard ${ }_{i t}$,

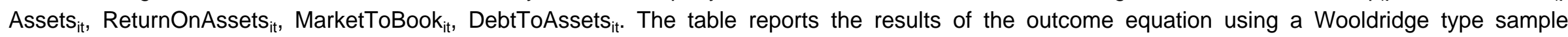
selection model. Figures below coefficients are standard errors which are robust to heteroskedasticity and autocorrelation. ${ }^{* * *},{ }^{* *},{ }^{*}$ indicate statistical significance at 1, 5, and 10 percent, respectively. 
Table AIV - Linear models with sector-year and company fixed effects (augmented models) including abnormal coverage limit as additional regressor (Dependent variable is the log insurance premium in year $t$ )

\begin{tabular}{|c|c|c|c|}
\hline Variable & Acronym & Model A & Model B \\
\hline \multirow{2}{*}{ Interaction Term Between ChangeShareholders ${ }_{i t}$ and CVPrice ${ }_{i t}$} & ChangeSh $_{i t} \times C V P_{i t}$ & $0.590^{*}$ & \\
\hline & & 0.305 & \\
\hline \multirow[t]{2}{*}{ Interaction Term Between NewShareh ${ }_{\text {it }}$ and CVPrice ${ }_{i t}$} & $\mathrm{NewSh}_{\mathrm{it}} \mathrm{xCVP} \mathrm{P}_{\mathrm{it}}$ & & -0.229 \\
\hline & & & 0.221 \\
\hline \multirow[t]{2}{*}{ Change in the Number of Common Shareholders Between Years $t$ and $t-1$} & ChangeShareholders $_{\text {it }}$ & $-0.100^{*}$ & \\
\hline & & 0.051 & \\
\hline \multirow[t]{2}{*}{ Log Number of New Institutional Shareholders in Year t } & NewShareh $_{\text {it }}$ & & $0.159^{*}$ \\
\hline & & & 0.082 \\
\hline \multirow[t]{2}{*}{ Coefficient of Variation of the Share Price for Year $t$} & CVPrice $_{i t}$ & 0.480 & 1.438 \\
\hline & & 0.407 & 0.873 \\
\hline \multirow[t]{2}{*}{ Abnormal coverage limit } & AbnCovLimit $_{\text {it }}$ & $0.432^{\star \star \star}$ & $0.486^{\star \star \star}$ \\
\hline & & 0.113 & 0.000 \\
\hline \multirow[t]{2}{*}{ Share of Independent Directors in the Company's Total Directors in percent in Year t } & Sharelndep $_{\text {it }}$ & -0.005 & 0.009 \\
\hline & & 0.006 & 0.006 \\
\hline \multirow[t]{2}{*}{ Log of Independent Directors' Years on Company's Board in Year t } & YearsonBoard $_{\text {it }}$ & -0.109 & -0.036 \\
\hline & & 0.135 & 0.113 \\
\hline \multirow[t]{2}{*}{ Log of Company' s Total Assets for Year t } & Assets $_{\text {it }}$ & $0.342^{\star \star \star}$ & $0.231^{\star \star \star}$ \\
\hline & & 0.084 & 0.087 \\
\hline \multirow[t]{2}{*}{ Company's Return on Assets for Year t } & ReturnOnAssets ${ }_{\text {it }}$ & 0.005 & 0.000 \\
\hline & & 0.004 & 0.004 \\
\hline \multirow[t]{2}{*}{ Company's Market to Book Ratio for Year t } & MarketToBook $_{\text {it }}$ & 0.002 & -0.002 \\
\hline & & 0.005 & 0.004 \\
\hline \multirow[t]{2}{*}{ Company's Debt Asset Ratio for Year t } & DebtToAssets $_{\text {it }}$ & -0.002 & -0.507 \\
\hline & & 0.423 & 0.424 \\
\hline Observations & & 418 & 372 \\
\hline Adj. $R^{2}$ & & 0.920 & 0.952 \\
\hline
\end{tabular}

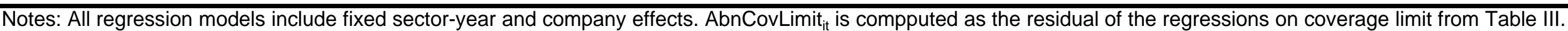

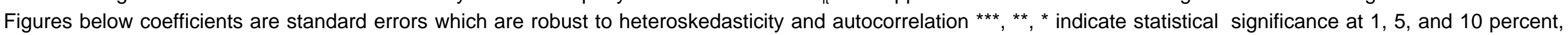
respectively (using two-tailed test statistics). 
Table AV - Linear models with sector-year and company fixed effects (augmented models) including additional controls as in Core (1997)

\begin{tabular}{|c|c|c|c|c|c|}
\hline \multirow[t]{2}{*}{ Variable } & \multirow[t]{2}{*}{ Acronym } & \multicolumn{2}{|c|}{$\begin{array}{l}\text { Log Coverage as a } \\
\text { dependent variable }\end{array}$} & \multicolumn{2}{|c|}{$\begin{array}{l}\text { Log Premium as a } \\
\text { dependent variable }\end{array}$} \\
\hline & & Model A & Model B & Model A & Model B \\
\hline \multirow[t]{2}{*}{ Interaction Term Between ChangeShareholders ${ }_{i t}$ and CVPrice $_{i t}$} & ChangeSh $_{\text {it }} \times \mathrm{CVP}_{\text {it }}$ & $0.490^{\star \star}$ & & $0.722^{\star \star}$ & \\
\hline & & 0.223 & & 0.322 & \\
\hline \multirow[t]{2}{*}{ Interaction Term Between NewShareh ${ }_{i t}$ and CVPrice $_{i t}$} & $\mathrm{NewSh}_{\mathrm{it}} \mathrm{XCVP}_{\mathrm{it}}$ & & $0.742^{\star \star \star}$ & & -0.074 \\
\hline & & & 0.208 & & 0.248 \\
\hline \multirow[t]{2}{*}{ Change in the Number of Common Shareholders Between Years $t$ and $t-1$} & ChangeShareholders $_{\text {it }}$ & $-0.085^{\star \star}$ & & $-0.122^{\star \star}$ & \\
\hline & & 0.037 & & 0.054 & \\
\hline \multirow[t]{2}{*}{ Log Number of New Institutional Shareholders in Year t } & NewShareh $_{\text {it }}$ & & 0.092 & & $0.234^{* *}$ \\
\hline & & & 0.080 & & 0.096 \\
\hline \multirow[t]{2}{*}{ Coefficient of Variation of the Share Price for Year $t$} & CVPrice $_{i t}$ & $0.890^{\star * *}$ & $-2.196^{\star \star \star}$ & 0.442 & 0.733 \\
\hline & & 0.294 & 0.820 & 0.442 & 0.980 \\
\hline \multirow[t]{2}{*}{ Share of Independent Directors in the Company's Total Directors in percent in Year t } & Sharelndep $_{\text {it }}$ & $0.010^{\star \star}$ & 0.002 & -0.012 & 0.001 \\
\hline & & 0.005 & 0.006 & 0.007 & 0.007 \\
\hline \multirow[t]{2}{*}{ Log of Independent Directors' Years on Company's Board in Year t } & YearsonBoard $_{\text {it }}$ & 0.132 & 0.116 & -0.058 & 0.066 \\
\hline & & 0.104 & 0.113 & 0.155 & 0.137 \\
\hline \multirow[t]{2}{*}{ Log of Company' s Total Assets for Year t } & Assets $_{i t}$ & $0.360 * * *$ & $0.303^{\star \star \star}$ & $0.411^{\star \star *}$ & $0.320^{\star \star \star}$ \\
\hline & & 0.062 & 0.083 & 0.094 & 0.101 \\
\hline \multirow[t]{2}{*}{ Company's Return on Assets for Year t } & ReturnOnAssets $_{\text {it }}$ & 0.003 & 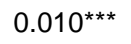 & 0.006 & 0.003 \\
\hline & & 0.003 & 0.003 & 0.004 & 0.004 \\
\hline \multirow[t]{2}{*}{ Company's Market to Book Ratio for Year $t$} & MarketToBook $_{\text {it }}$ & -0.001 & 0.003 & 0.002 & 0.000 \\
\hline & & 0.004 & 0.004 & 0.006 & 0.005 \\
\hline \multirow[t]{2}{*}{ Company's Debt Asset Ratio for Year t } & DebtToAssets $_{i t}$ & -0.375 & 0.582 & 0.219 & -0.087 \\
\hline & & 0.307 & 0.403 & 0.464 & 0.480 \\
\hline \multirow[t]{2}{*}{ Indicator Variable of Disclosed Prior or Pending Litigation for Year t } & LitDisc $_{\text {it }}$ & 0.120 & 0.150 & 0.082 & 0.157 \\
\hline & & 0.144 & 0.164 & 0.240 & 0.210 \\
\hline \multirow[t]{2}{*}{ Insider Ownership for Year $\mathrm{t}$} & InsValue $_{\mathrm{it}}$ & 0.092 & 0.240 & -0.313 & -0.137 \\
\hline & & 0.495 & 0.524 & 0.770 & 0.663 \\
\hline \multirow[t]{2}{*}{ Indicator Variable of Divestiture in Year t } & Divest $_{\text {it }}$ & 0.052 & 0.137 & 0.240 & $0.267^{*}$ \\
\hline & & 0.127 & 0.135 & 0.186 & 0.160 \\
\hline \multirow[t]{2}{*}{ Standardized Residual of Director Cash Compensation on its Determinants for Year t } & ExcessPay $_{\text {it }}$ & -0.005 & -0.022 & 0.025 & 0.041 \\
\hline & & 0.041 & 0.046 & 0.060 & 0.055 \\
\hline Observations & & 407 & 363 & 389 & 347 \\
\hline Adj. $R^{2}$ & & 0.950 & 0.950 & 0.920 & 0.950 \\
\hline
\end{tabular}

Notes: All regression models include fixed sector-year and company effects. Figures below coefficients are standard errors which are robust to heteroskedasticity and autocorrelation ***, **, * indicate statistical significance at 1, 5, and 10 percent, respectively (using two-tailed test statistics). 